\title{
Condition Factor Analysis in the Region of South Bohemia
}

\author{
Petra Pártlová ${ }^{*}$ \\ ${ }^{1}$ Institute of Technology and Business in České Budějovice, Faculty of Corporate Strategy, Okružní \\ 517/10, 37001 České Budějovice, Czech Republic
}

\begin{abstract}
Socio-economic transformation in many post-communist states has influenced the dynamic process in such states with the differentiation trends. Such process often causes disparities in different regions, creates relations and ties, often contradictory, and spatial socio-economic polarization in the regions. The above-mentioned processes and their impacts are demonstrated on the example of the South Bohemian region, in particular the LAG territory. Using the methods of correlation analysis, the author demonstrates the conditionality of the indicators in the area of interest. Different links and relations of socio-economic, infrastructural and natural factors to the emergence of disparities in different LAGs are analyzed. The most important factors of the emerging disparities within the region and the LAGs include the relations between the progressiveness of the economic structure and population density and between the demographic structure of the region and the infrastructure, as revealed by the analysis.
\end{abstract}

Key words: conditionality factors, South Bohemia Region, correlation analysis

\section{Introduction}

In connection with the changes in the theory of regional sciences [1], regional studies and the related issues of rural areas have developed significantly in recent [2]. Similarly, in space polarization research localization theories were applied significantly [3], based on the work of TJH von Thünen, A. Weber.

Efforts to deal with regional disparities followed, especially within the theory of the core-periphery of Myrdal [4], Perroux [5], quoted in Havlíček et al. [6] and in particular Friedmann [7] and his theory of polarized development.

It was Friedmann who introduced the term of core-periphery. Leimgruber [8] then explains the relations and links that affect the differentiation of the territory, arguing that peripheral areas should be assessed from an economic perspective, however also social, political, cultural and environmental aspects and their impact on these peripheral regions should be taken into account.

A significant change is related to the shift from the study of general issues of regional system development to the study of problem areas, respectively the shift from extensive forms of regional research to a combination of extensive and intensive research [3].

\footnotetext{
*Corresponding author: partlova@email.vstecb.cz
} 
Similarly, Havlíček and Chromý [9] note that the periphery is a specific area with a disturbance of functional-spatial and socio-spatial relations, as the result of uneven influence of mutually conditioned social, economic, political, cultural and physicalgeographical factors. They refer to peripheral territories as such areas located outside economically intensively exploited areas, characterized as remote from residential centers. Such areas are also identified by poor traffic conditions, poor transport accessibility, and low population density. The assessment of the factors affecting regional development of post-communist states and regions is addressed by many authors.

Havlíček and Chromý [9] worth mentioning in relation to the development of the regional structure of the Czech Republic. The authors divide the conditioning factors affecting the development of regions into three categories: (1) geographical factors (natural conditions and resources, settlement hierarchy, geographical location) (2) socio-economic factors (capital, human resources and specific economic factors - technological maturity, technical and social infrastructure and socio-economic intensity of land use), (3) sociocultural factors (tradition, cultural capital, etc.).

Most authors focus on a particular area only, influenced by conditioning factors. Pileček, and Müller [10] deal with the conditionality of the factor on differentiation of unemployment. Netrdová, and Nosek [11] focus on the area of population differentiation. Blažek and Netrdová, [12] investigate the conditionality of several factors. In particular, they deal with the unemployment rate, the intensity of housing construction and voter turnout. Novotný, Janská and Čermáková [13] study the placement of foreigners in the Czech Republic and its conditioning factors. Socio-cultural conditionality and evaluation of natural and cultural and landscape heritage for the development of tourism are discussed by Chromý, Semian and Kučera [14].

The conditionality of transport opportunities is discussed by Květoň and Marada [15]. Most of the studies are focused mainly on the regions and districts. Studies are much less concerned with research at municipal level. However, there are several studies dealing with the differentiation of lower territorial units. These include the following authors: Musil, Müller; Blazek, Netrdova; Perlin, Kucerova, Kucera; Novak, Netrdova and Maceskova, Ourednicek, Temelova [16], [12], [17-19]. In Slovakia, the issue is discussed by Buček, Korec, Ira et al., Korec, Ondoš. [20-24].

\section{Data and methods}

The research used secondary data from Ekotoxa. The data were divided into four pillars (economic, social, infrastructure-institutional and environmental). In total, 602 municipalities in 17 local action groups of the South Bohemian Region were analyzed, except for towns with a population of over 25,000 , i.e. all municipalities that may be part of a regional LAG.

A total of 29 indicators were selected. The proposed and subsequently selected indicators were consulted by CzechInvest and some adjustments of the indicators were made by Ekotoxa.

Finally, four indicators were selected in the economic pillar (Progressivity Index of the Economic Structure, Trend of Progressivity Index of the Economic Structure, Rate of Business Activity, Natural Presumptions of Recreation); seven indicators in the social pillar (Population Density, Aging Population, Economic Load Index Trend, Natives, Higher Education Trend, Unemployment Trend, Czech Citizenship); eleven indicators in infrastructure (Accessibility of the area by the public transport on Saturday, Accessibility of the area by $\mathrm{A}$ and major roads, Accessibility of railway stations, Residents living in permanently occupied dwellings connected to water supply, gas and public sewerage, Nursery school facilities, Primary school facilities, Accessibility of secondary schools with 
Maturita, Accessibility of senior care homes, Adult general practice , Availability of hospitals and outpatient facilities); and seven indicators in the environmental pillar (Production capacity of land resources, Ecological fragmentation, Share of water areas, Chemical status of surface water, Soil visualization trend, Forest hazard zones, T specific territorial emissions from stationary sources). The indicators were assigned codes from K101 to K407.

Subsequently, the data were compared in order to determine the conditionality of different factors, both within different pillars and within the same pillars, and to determine the spatial differentiation of conditional factors on four pillars in the South Bohemian region. A correlation analysis method was used. The correlation analysis is focused on finding the intensity of potential dependencies between random variables of the sample. The result of the analysis is to determine the degree of dependence, by calculating the values of different types of correlation coefficients (such as Pearson and Spearman correlation coefficient).

Using the Pearson correlation analysis is conditioned [25] by normal probability distribution of the data with an expected linear relation.

The Pearson correlation coefficient of $r$ is the most important measure of the strength of the relation of two random continuous variables X and Y [26]. Correlation coefficients (rP) determine the degree of tightness (force) of the relation between two variables, taking values $-1 \leq r \leq+1$ and at $r=0$ the variables $X$ and $Y$ are completely independent (discontinuous, unrelated).

The higher the value of the correlation coefficient, the higher is the dependency (in causal relation and the association (in association relation) between $X$ and $Y$ variables. If $r$ is positive, then the value of $Y$ increases with increasing value of $X$.

If $r$ is negative, the value of $Y$ decreases with an increasing value of $X$. There is a causal relation between $\mathrm{X}$ and $\mathrm{Y}$ if $\mathrm{X}$ unequivocally causes and affects $\mathrm{Y}$ (a change in $\mathrm{X}$ causes a change in $\mathrm{Y}$ ). In the association relation in influencing, changing $\mathrm{X}$ (or Y), Y (or X) also changes, but we do not know whether this change is caused by $\mathrm{X}$ or $\mathrm{Y}$ or another variable. An independent variable is a property (phenomenon) that is the cause or condition of the occurrence of another property (phenomenon). A dependent variable is a property that is the result (consequence) of the action of an independent variable. Pearson's correlation coefficient should not be used if one of the variables $\mathrm{X}, \mathrm{Y}$ is not random (its values are fixed), the linearity of the expected relation is not assumed, nor the normal distribution of the variables $\mathrm{X}$ and $\mathrm{Y}$.

Person correlation coefficient is calculated directly from the paired values of the $\mathrm{X}$ and $\mathrm{Y}$ variables. Similarly, to the arithmetic mean and standard deviation, it is greatly influenced by outliers. Person rp is defined as the mean value of the product of standardized random variables:

$$
r_{p}=\frac{n \cdot \sum_{i=l}^{n} x_{i} y_{i}-\sum_{i=l}^{n} x_{i} \cdot \sum_{i=l}^{n} y_{i}}{\sqrt{\left[n \cdot \sum_{i=l}^{n} x_{i}^{2}-\left(\sum_{i=l}^{n} x_{i}\right)^{2}\right] \cdot\left[n \cdot \sum_{i=l}^{n} y_{i}^{2}-\left(\sum_{i=l}^{n} y_{i}\right)^{2}\right]}}
$$

Explanatory notes:

$r_{p}$ - Pearson correlation coefficient

$\mathrm{n}$ - Number of pairs compared

$\mathrm{x}$ - Dependent variable

y - Independent variable

Hendl defines the strength of the relation as [26]:

Weak if $\left|r_{p}\right|=0.1$ to 0.3 .

Medium if $\left|r_{\mathrm{p}}\right|=0.3$ to 0.7 .

Strong if $\left|r_{p}\right|=0.7$ to 1 . 
Interpretation of the force of dependence of the variables by the correlation coefficient is influenced by the number of the analyzed data (and measured values). Therefore, the statistical test, and the tables of statistical significance for Person correlation coefficient are used. The test significance of the statistical significance test for the correlation coefficient is $\mathrm{H} 0: \mathrm{r}=0$. If the test hypothesis is rejected at a significance level (such as $\alpha=0.05$ ), it is possible to accept the result of calculating the correlation coefficient as statistically significant́

\subsection{Analysis of conditionality factors in the pillars of the region of South Bohemia}

Person correlation was used to find out all combinations of dependence between the proposed indicators for the rural area of the region of South Bohemia. The resulting matrix shows that the dependence manifested across the pillars.

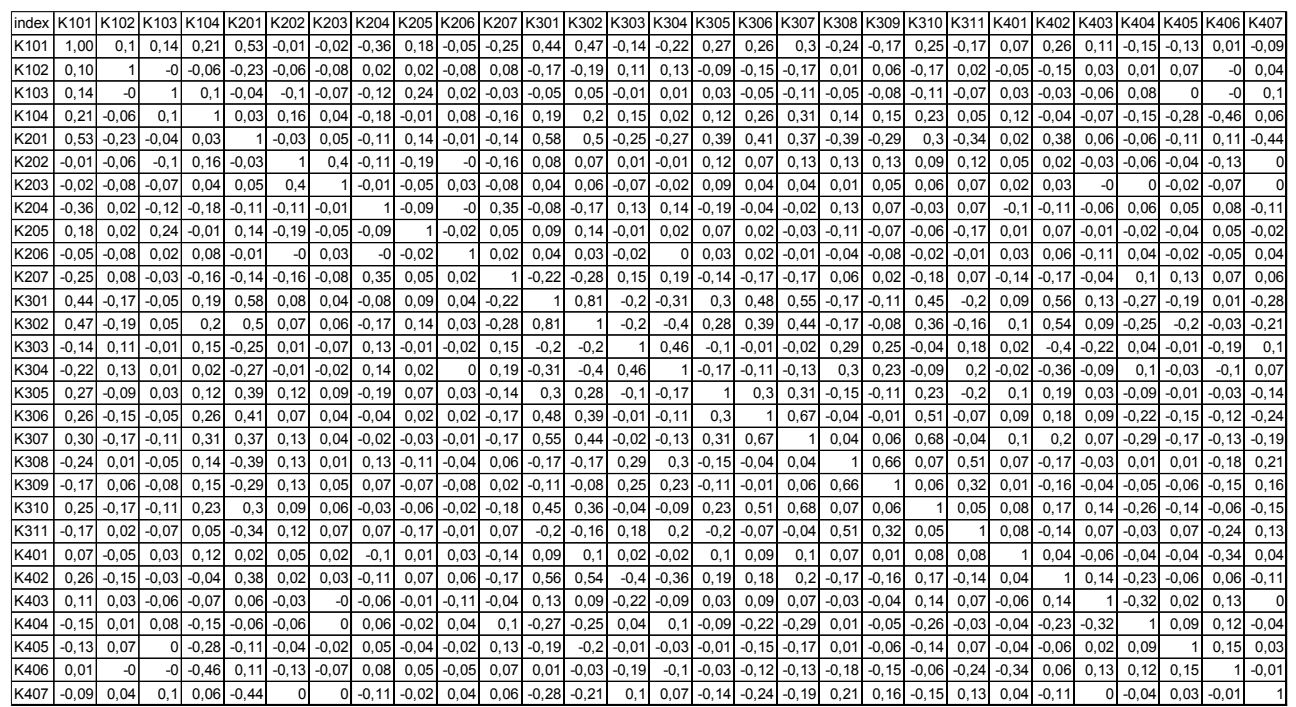

Fig. 1: Correlation matrix

Source: Own processing.

Legend:

K101 Progressivity Index of the Economic Structure

K102 Trend of Progressivity Index of the Economic Structure K103 Rate of Business Activity

K104 Natural Presumptions of Recreation

K201 Population Density

K202 Aging Population

K203 Economic Load Index Trend

K204 Natives

K205 Higher Education Trend
K305 Residents living in permanently occupied dwellings connected to water supply, gas and public sewerage

K306 Nursery school facilities

K307 Primary school facilities

K308 Accessibility of secondary schools with Maturita

K309 Accessibility of senior care homes

K310 Adult general practice

K311 Availability of hospitals and outpatient facilities

K401 Production capacity of land resources

K402 Ecological fragmentation 
K206 Unemployment Trend

K207 Czech Citizenship

K301 Availability by public transport on weekdays

K302 Accessibility of the area by the public transport on Saturday

K303 Accessibility of the area by A and major roads
K403 Share of water areas

K404 Chemical status of surface water

K405, Soil visualization trend

K406 Forest hazard zones

K407 T specific territorial emissions from stationary sources

K304 Accessibility of railway stations

\section{Results}

\subsection{The economic pillar versus the social pillar}

In the economic pillar, the dependence between the indicator of progressiveness of the economic structure and population density was revealed. Significance between these factors was confirmed and the low value of the indicator of progressivity of economic structure and low value of population density is confirmed mostly in economically weak or rural municipalities, some of them characterized as peripheral, in the long-term (such as the rural area near the Central-South Bohemian administrative boundary - LAG Blatensko, LAG Brána Písecka and LAG Krajina Srdce (Landscape of the Heart), LAS Střední Povltaví, LAG Vltava), defined by low population density and a permanent outflow of population. The above-mentioned indicator is also related to the Natives indicator, defined as share of people born in the municipality of their permanent residence. The results proved the dependence in the LAG Landscape of the Heart, the LAG Strední Povltaví and the LAG Blatensko and also in the peripheral region of the LAG Czech Canada, administratively adjacent to the Vysočina region. The dependence was not found in in the LAG of Brána Písecka area, the reason may be an increase in new business locations in this area due to higher relocation to this region, due to job opportunities.

\subsection{The economic pillar versus the infrastructure pillar}

Another indicator that affects the progressiveness of the economic structure is the Accessibility of the area by the public transport on weekdays and on Saturdays. The worst situation is in the Lužnice LAG, whose average number of connections per day is 23 ; and 4 on Saturdays, followed by the Blatensko LAG with 29 (4) connections; with the same result, surprisingly in the Třeboňsko LAG 29 (7) and Krajina Srdce 29 (7) and LAG Strakonicko 33 (4). On the other hand, the LAGs of Lužnicko, Hlubocko-Lišovsko, Sdružení Růže and Pomalší are the best. From the results, it is possible to point out the possibility of direct connection of business structure, concentration of the enterprises and job opportunities, higher level of services to the attractiveness of settlements and regions. It can also be verified from the map data obtained that the size of settlements closely correlates with the size of the enterprises. And it is also possible to observe that the development of smaller settlements arises around large settlements by the process of suburbanization, where there is an apparent increase in connections mainly on weekdays.

\subsection{The economic pillar versus the environmental pillar}

Natural potential for recreation and forest zoning is discussed. The functionality of forests (Vyskot, 2000), and changes in these functions in the forest ecosystem are proved. Forest zoning affects the socio-recreational potential of the forest. Such potential is quantified. 
The highest socio - recreational potential is, for example, in forests of national parks and spa forests. On the contrary, the lowest value of forests is related to those anthropogenically degraded. The analysis revealed the highest natural potential for recreation in the regions of the Šumavsko LAG, the Rozkvět LAG, the Růže LAG and the Česká Kanada LAG. On the contrary, the worst situation appears in the LAGS of LAG Blatensko, Strakonicko and Vodňanská Ryba.

\subsection{The social pillar versus the infrastructure pillar}

In the social pillar, a significant dependence between demographic structure and infrastructure was found [28-32]. Demographic factors are undoubtedly among the indicators affecting the accessibility of public transport in regions and municipalities. As an example, there are the remote locations, both poor and peripheral rural areas, mostly small settlements with low population density, very often accompanied by inaccessibility. It is the peripheral location of the area that is one of the external causes that indirectly affects the location of services and job opportunities. Such significance applies in the LAGs of Třeboňsko 29 (7) and Krajina Srdce with 33 (7) public transport connections, both on weekdays and Saturdays.

There are also significant dependencies between the number of public bus services and the population size of the settlement. There is a direct dependence and a direct rate between a higher rate of public transport service and a higher population in settlements. This dependence was not confirmed for rail transport, probably explained by the fact that there is no mass construction of railways, as is the case with roads, the railways are only modernized. It is interesting to note that the dependence of unemployment on transport infrastructure was not proved [33]. This may be the result of a relatively largely motorized countryside in response to a reduction in the number of public bus and rail services in the 1990s. It is therefore clear that peripheral rural regions, and structurally affected areas suffering from high unemployment, are less motorized and public transport is also of social importance.

\subsection{Dependencies of the infrastructure pillar indicators on the environmental pillar}

Based on the analysis of the results, the impact of ecological fragmentation on transport services was proved to be a very important factor. It was proved that higher fragmentation of the settlement system (fragmentation of municipalities, i.e. more local parts) negatively affects the provision of transport services by public transport and vice versa. It was also shown that at the level of basic settlement units there is a traffic exclusion of the population, which is caused by the unavailability of public transport and hence the absence of a transport alternative [34].

\subsection{Reciprocal dependencies in the infrastructure pillar}

The results of the analysis showed a mutual interaction between transport services and the number of primary and nursery schools [35]. The relation of spatial exclusion is confirmed, i.e. low number of public transport services to remote places with low population density per capita to density of the socially excluded persons (for example children and adolescents). Spatial exclusion is a specific case where the distance of localities in the territory is in direct relation very often accompanied by traffic unavailability. It is the peripheral location of the settlement that is one of the external causes that cannot be influenced by the availability of public services (nursery and primary schools). Children 
and adolescents who do not have a driving license and who cannot directly influence the location of basic public services (number of connections). The age of the population, which determines their transport possibilities, is a factor beyond control.

\subsection{Reciprocal dependence in the social pillar}

Interdependencies were also proved for the social pillar indicators, in particular population density with the trend of the economic burden index. It can be inferred from this dependence that the lower the value of the economic load index, the more favorable is the ratio between the economically inactive and the active population. The population is not aging in the region [36]. Indications of this dependence, with lower population density and lower value of the economic burden index, occur in the regions of the Rozkvert and Sdružení Růže LAGs. Conversely, this is not true in the LAGs of Lužnicko, Strakonicko, Blanský les and Česká Kanada (these are typical peripheral regions where this trend is very significant).

A lower dependency was also found for the indicator of "the natives" and the share of the population with Czech citizenship. Such signification was proved to be very dependent in the LAGs of Krajina Srdce and Střední Povltaví regions, where there is a high proportion of inhabitants born in the municipality of mother's permanent residence and at the same time these regions have a high proportion of inhabitants with Czech citizenship. On the contrary, there is the LAG of Pomalší with the largest share of the population is from Slovakia and Ukraine. It can be assumed that the inhabitants of these countries moved to the region to take advantage of the labor market opportunities.

\subsection{Reciprocal dependencies in the environmental pillar}

The research showed that there is interdependence between the variables in the environmental pillar. It proved that there is a degree of dependence between forest zoning and soil production capacity. The regions with lower soil production potential report a higher zone of forest threat, such as in the regions of LAGs of Blatensko, Strední Povltaví, Brána Písecka, Krajina srdce, Vodňanská ryba, and Strakonicko. To the contrary, the with higher soil production potential have lower forest threat zones, such as the LAGs of Šumavsko, Sdružení Růže, Rozkvět, and Pomalší. It should be noted here that mountain forests are currently endangered by spruce bark beetle. This disrupts the forest zonation and there has been a greater threat to these forests in the last decade. However, it should be noted that in Šumava, where the largest forest zoning in the South Bohemian Forest Region has occurred, repeated large-scale disturbance of spruce stands has occurred in the last at least 3,000 years, with a period of approximately 180 years [37]. Then spontaneous forest ecosystem recovery is successful [38].

\section{Conclusion}

The study of spatial differentiation based on the analysis of four pillars (economic, social infrastructure and environmental) is an important perspective on the identification of conditional dependencies in the LAGs of the research, within two different pillars, and the reciprocal dependence of one pillar. It is also interesting to find out the individual regional dependencies, which are reflected in the differentiation of regions in the South Bohemian region and it is possible to distinguish between developing and lagging regions and rural environmental regions and other rural urban regions, such as suburbia. 
The aim of this research was to assess the impact of different factors on the territorial disparities of LAG regions in the South Bohemian Region. As revealed by the research, worse results in the economic pillar also correlate with indifferent and worse results in the social pillar as revealed in the LAGs of Střední Povltaví, Vltava, Krajina Srdce and Blatensko.

In the LAGs of Krajina srdce and Blatensko the dependencies of infrastructural pillars and the availability of the area by public transport on weekdays were further confirmed. All the above-mentioned LAGs also occurred in assessing the dependence of the social pillar on infrastructure. These regions are largely represented by poor and peripheral communities with low population density. Here, it is interesting to point out the fact that a relation of unemployment in the transport infrastructure was not proved. The indicator of lower population density showed another dependence on the economic burden index - the lower the population density in the regions, the lower the value of the economic burden index. Such dependency was manifested, for example, in the regions of Rozkvět LAG and Sdružení Růže LAG. The analysis of the correlation of the economic and environmental pillar revealed that the regions of the LAGS of Šumava, Rozvět and Sdružení Růže had the greatest potential for recreation. The worst situation was in the LAG of Blatensko. Similarly, these regions (LAGs of Šumavsko, Rozvět and Sdružení Růže) have higher soil production potential and lower forest threat zones. The results of the correlation showed also other dependencies, although not so significant. However, common characteristics are seen in some LAGs. Certainly, it would be appropriate in further research to create more common characteristics from the pillars under review to reveal similarity patterns according to differentiated territory.

\section{Acknowledgements}

This article was supported by the project "Stabilization and development of SME in rural areas", reg. No. TL01000349, the TACR Éta programme.

\section{References}

1. J. Blažek, D. Uhlír, Teorie regionálního rozvoje: nástin, kritika, implikace [Theory of regional development: outline, criticism, implication]. Prague: Karolinum, 343 (2011)

2. M. Hampl, Regional differentiation of current socio-economic development in the Czech Republic. Czech Sociological Review, 43(5), 889-910 (2007)

3. J. Blažek, Regionální inovační systémy a globální produkční sítě: dvojí optika na zdroje konkurenceschopnosti v současném světě [Regional innovation systems and global production networks: Two views on the source of competitiveness in the present-day world?]. Geografie, 117(2), 209-233 (2012)

4. G. Myrdal, Economic Theory and Underdeveloped Regions. London: Duckworth, (1957)

5. F. Perroux, Note sur la notion de pole de croissance [Note on the concept of growth pole]. Economique Applique, 8(1-2), 307-320 (1955)

6. T. Havlíček, V. Jančák, P. Chromý, M. Marada, Vybrané teoreticko-metodologické aspekty a trendy geografického výzkumu perifernich oblastí [Selected theoreticalmethodological aspects and trends of geographic research of peripheral areas]. In: M. Novotná (ed.): Problémy periferních oblastí [Problems of peripheral areas], KSGRR Faculty of Science, Charles University, Prague, 6-24 (2005) 
7. J. Friedmann, Regional Development Policy: A Case Study of Venezuela. M.I.T. Press (1966)

8. S. Leimgruber, Investigation of the Rubber-Brass Adhesion Layer Using the OlefinMetathesis Method. Rubber Chemistry and Technology, 88, 219-233 (2015)

9. T. Havlíček, P. Chromý, Př́spěvek k teorii polarizovaného vývoje území se zaměřením na periferní oblasti [Contribution to the theory of polarized development of a territory, with a special attention paid to peripheral regions]. Geografie, 106(1), 1-11 (1966)

10. J. Pileček, J. Müller, Regionální disparity ve vývoji nezaměstnanosti v období hospodářské krize [Regional disparities in the development of unemployment in times of economic crisis]. Regionální disparity a hospodářské subjekty v regionálním rozvoji [Regional disparities and economic operators in regional development], p. 74-87 (2010)

11. P. Netrdová, V. Nosek, Přístupy $\mathrm{k}$ měření významu geografického rozměru společenských nerovností [Approaches to measuring the importance of the geographical dimension of social inequalities]. Geografie, 114(1), 52-65 (2009)

12. J. Blažek, P. Netrdová, Regional unemployment impacts of the global financial crisis on the new member states of the EU in Central and Eastern Europe. European Urban and Regional Studies, 19(1), 42-61 (2012)

13. J. Novotný, E. Janská, D. Čermáková, Rozmístění cizinců v Česku a jeho podmiňující faktory: pokus o kvantitativní analýzu [Distribution of foreigners in the Czech Republic and its conditioning factors: an attempt at quantitative analysis]. Geografie, 112(2), 204-220 (2007)

14. P. Chromý, M. Semian, Z. Kučera, Regionální vědomí a regionální identita v Česku: prŕpadová studie Českého ráje [Regional awareness and regional identity in the Czech Republic: a case study of the Bohemian Paradise]. Geografie, 119(3), 259-277 (2014)

15. V. Květoň, M. Marada, Diferenciace nabídky dopravních př́ležitostí v českých obcích a sociogeografických mikroregionech [Differentiation of transport opportunities in Czech municipalities and socio-geographic micro-regions]. Geografie, 115(1), 21-43 (2010)

16. J. Musil, J. Müller, Vnitřní periferie v České republice jako mechanizmus sociální exkluze [Internal periphery in the Czech Republic as a mechanism of social exclusion]. Sociologický časopis, 44(2), 321-348 (2008)

17. R. Perlín, S. Kučerová, Z. Kučera, Typologie venkovského prostoru Česka [Typology of rural space in the Czech Republic]. Geografie, 115(2), 161-187 (2010)

18. J. Novák, P. Netrdová, Prostorové vzorce sociálně-ekonomické diferenciace obcí v České republice [Spatial patterns of socio-economic differentiation of municipalities in the Czech Republic]. Sociologický časopis, 47(4), 717-744 (2011)

19. M. Macešková, M. Ouředníček, J. Temelová. Sociálně prostorová diferenciace v České republice: implikace pro veřejnou (regionální) politiku [Socio-spatial differentiation in the Czech Republic: implications for public (regional) policy]. Ekonomický časopis, 57(7), 700-715 (2009)

20. M. Buček, Regionálna integrácia Slovenskej republiky: stratégia využitia podpory Európskej únie [Regional integration of the Slovak Republic: strategy of using the support of the European Union]. Ekonomický časopis, 51(8), 982-996 (2003)

21. P. Korec, Regionálny rozvoj Slovenska v rokoch 1989-2004 [Regional development of Slovakia in 1989-2004]. Geo-grafika (2005) 
22. V. Ira, L. Falt’an, J. Pašiak, P. Gladoš, Podoby regionálnych odlišností na Slovensku [Forms of regional differences in Slovakia]. Sociologický ústav (2005)

23. P. Korec, S. Ondoš, Less developed regions of Slovakia: identification and characteristics. Acta Geographica Universitatis Comenianae, 48, 55-74 (2006).

24. P. Korec, S. Ondoš, Historické a geografické aspekty regionálnej divergencie na Slovensku [Historical and geographical aspects of regional divergence in Slovakia]. In S. Kraft, K. Mičková, J. Rypl, P. Švec, M. Vančura. eds.: Česká geografie v evropském prostoru [Czech geography in European space], 626-631 (2007)

25. M. Meloun, J. Militký, Interaktivní statistická analýza dat [Interactive statistical data analysis]. Prague: Karolinum (2012)

26. J. Hendl, Přehled statistických metod zpracování dat: analýza a metaanalýza dat [Overview of statistical methods of data processing: data analysis and meta-analysis]. Prague: Portál (2004)

27. A. Vyskot, Kvantifikace a hodnocení funkci lesů České republiky [Quantification and evaluation of forest functions in the Czech Republic]. Prague: Ministry of Environment (2003)

28. S. Nutley, Rural Areas Accessibility Problem. In: B. Hoyle, R. Knowles eds.: Modern Transport Geography, 2nd rev. ed., Wiley and sons, Chichester, 185-215 (1998)

29. M.J. Dargay, Determinants of car ownership in rural and urban areas: a pseudo-panel analysis. Transportation Research Part, 38, 351-366 (2002)

30. J. Farrington, C. Farrington. Rural accessibility, social inclusion and social justice: towards conceptualisation. Journal of Transport Geography, 13, 1-12 (2005).

31. J. Mcdonagh. Transport policy instruments and transport-related social exclusion in rural Republic of Ireland. Journal of Transport Geography, 14, 355-366 (2006)

32. M. Marada, T. Hudeček, Accessibility of Peripheral Regins: A Case of Czechia. EUROPA XXI, Institute of Geography and Spatial Organization, Warszawa, p. 43-49, (2006)

33. K. Inhlanfeldt, D. Sjoquist, The spatial mismatch hypothesis: a review of recent studies and their implications for welfare reform. Housing Policy Debate, 9, 849-892 (1998)

34. V. Květoň, J. Chmelík, P. Vondráčková, M. Marada, Developments in the public transport serviceability of rural settlements with examples from various types of microregions. Acta Universitatis Carolinae - Geographica, 1/2012,51-63 (2012)

35. V. Hulík, K. Tesárková, K., Dopady demografického vývoje na vzdělávací soustavu v České republice [Impacts of demographic development on the educational system in the Czech Republic]. Orbis Scholae, 3(3), 7-23 (2009)

36. S. Kučerová, Z. Kučera, Vztah periferiality a vzdělávání: Lze definovat periferní oblasti na základě vývoje sítě základních škol? [Relationship between peripheral and education: Is it possible to define peripheral areas based on the development of the network of primary schools?] Acta geographica Universitatis Comenianae, (53), 59-73 (2009)

37. H. Svobodová, Vývoj horských lesů na Šumavě [Development of mountain forests in the Bohemian Forest]. In: Z. Neuhäuslová et al., Mapa potenciální přirozené vegetace NP Šumava [Map of potential natural vegetation of Šumava National Park]. Silva Gabreta, Suppl. 1/2001 (2002)

38. M. Jonášová, K. Prach. Central-European mountain spruce (Picea abies (L.) Karst.) forests: regeneration of tree species after a bark beetle outbreak. Ecological Engineering, 23(1), 15-27 (2004) 